\title{
Sepsis due to Yersinia enterocolitica in an aborted equine fetus: case report
}

Sepse por Yersinia enterocolitica em um feto equino abortado: relato de caso

${ }^{1}$ Centro de Ciências Agroveterinárias - Universidade do Estado de Santa Catarina - CAV/UDESC, Lages, SC

${ }^{2}$ Centro de Diagnóstico Microbiológico Animal - CAV/UDESC - Lages, SC

${ }^{3}$ Veterinária autônoma - Bom Retiro, SC

\begin{abstract}
Yersinia enterocolitica is a bacterium with zoonotic potential and there are no previous records of this bacteria being isolated from aborted foals. This report aims to describe a case of sepsis due to Y. enterocolitica in a seven month old aborted equine. The fequinoetus was submitted to necropsy and samples of all the organs were collected for the histological exam. Samples of liver, lung, placenta, and stomach contents were collected for bacterial culture. Macroscopically, the liver was enlarged with yellowish heterogeneous color, heart with pale myocardial areas; lungs not collapsed, heavy and shiny, thickened umbilical cord covered with fibrin and pus. Histopathologically, there was moderate multifocal necrosuppurative myocarditis and thrombosis, moderate diffuse suppurative bronchopneumonia, mild multifocal fibrinonecrotic hepatitis, and moderate diffuse necrosuppurative omphalitis with intralesional bacterial myriads and thrombosis. Mild multifocal suppurative placentitis, nephritis, myositis, cystitis, and dermatitis were also observed, in addition to mild diffuse lymphoid rarefaction. The microbiological evaluation identified $Y$. enterocolitica in the liver, lung, and stomach fluid. This is the first report of sepsis due to $Y$. enterocolitica causing an abortion in a horse. This bacterium has zoonotic importance; therefore, it should be investigated in abortion in this species, serving as a differential diagnosis in reproductive disorders.
\end{abstract}

Keywords: bacterial disease, yersiniosis, zoonosis, herbivore, pathology

\section{RESUMO}

Yersinia enterocolitica é uma bactéria com potencial zoonótico, e não há informações desse agente como causa de abortamento em equinos. O objetivo deste relato é descrever um caso de sepse por Y. enterocolitica em um feto equino abortado aos sete meses. O feto foi submetido à necropsia, e amostras de todos os órgãos foram processadas para histopatologia. Para microbiologia, foram coletadas amostras de fígado, pulmão, placenta e conteúdo estomacal. Macroscopicamente, observou-se fígado aumentado com coloração amarelada heterogênea; coração com áreas pálidas no miocárdio; pulmões não colabados, pesados e brilhantes; e cordão umbilical espessado e recoberto por fibrina e pus. Na análise histopatológica, havia miocardite necrossupurativa multifocal moderada e trombose, broncopneumonia supurativa difusa moderada, hepatite fibrinonecrótica multifocal discreta e onfalite necrossupurativa difusa moderada com miríades bacterianas intralesionais e trombose. Observou-se também placentite, nefrite, miosite, cistite e dermatite supurativa multifocal discreta, além de rarefação linfoide difusa discreta. A avaliação microbiológica identificou Y. enterocolitica no fígado, no pulmão e no líquido estomacal. Este é o primeiro relato de sepse por Y. enterocolitica causando abortamento na espécie equina. Essa bactéria tem importância zoonótica, portanto deve ser investigada em casos de abortamento nessa espécie, servindo como diagnóstico diferencial em tal distúrbio reprodutivo.

Palavras-chave: doença bacteriana, yersiniose, zoonose, herbívoro, patologia

Recebido em 15 de junho de 2020

Aceito em 8 de setembro de 2020

*Autor para correspondência (corresponding author)

E-mail: renata.casagrande@udesc.br 


\section{INTRODUCTION}

Abortion and neonatal death are important factors in economic losses in equine breeding. Among the causes of abortion and placentitis in this species, bacteria are the most important diagnosed infectious agents, mainly Streptococcus equi subsp. zooepidemicus, Escherichia coli, Klebsiella pneumoniae, Actinobacillus equuli, Leptospira sp., and Salmonella sp., followed by viral and fungal agents (Laugier et al., 2011; Marenzoni et al., 2012). Yersinia enterocolitica is a gram-negative bacterium of the Enterobacteriaceae family, considered an important pathogen responsible for causing gastrointestinal and septicemic disorders in several species, including humans (Platt-Samoraj et al., 2010; Sauter et al., 2017). In 2012, the yersiniosis complex was considered the third most reported zoonotic disease in the European Union (The European..., 2012). Yersinia enterocolitica was the species most frequently identified among humans with yersiniosis, being described mainly in large outbreaks related to food contamination, including fatal cases (The European..., 2012; Longenberger et al., 2013).

As a primarily intestinal pathogen, the information described in the literature is related to microbiological isolation from organs of the gastrointestinal tract or feces, therefore, information about the injuries caused by this agent in other organs is very limited (Oellerich et al., 2007). This bacterium has been isolated in cases of abortion in buffaloes, sheep, and pigs (Das et al., 1986; Corbel et al., 1992; Platt- Samoraj et al., 2009). There is no information on $Y$. enterocolitica isolated from specimens of equine fetuses or associated with cases of abortions in the species. This report aims to describe a case of sepsis by $Y$. enterocolitica on an aborted equine fetus.

\section{CASUISTRY}

In November 2018, a Gipsy cob horse fetus aborted at seven months of gestation was sent to the Laboratory of Animal Pathology of the University of Santa Catarina State (UDESC) for anatomopathological examination. The clinical and reproductive history of the mare and information about the farm were obtained with the veterinarian responsible for clinical care.
During the necropsy, samples of all organs were collected, placed in $10 \%$ buffered formalin, routinely processed for histology and stained with hematoxylin and eosin for further analysis under optical microscopy. For bacterial culture samples of liver, lungs, placenta, and stomach contents were collected aseptically and refrigerated in sterile containers. For microbiological isolation, pre-enrichment was performed with $4 \mathrm{~g}$ of the sample and $196 \mathrm{ml}$ of sterile peptone water in a bag, followed by homogenization in Stomacher® 400 Circulator (Laboratory Blender-UK) and incubation for 24 hours at $37^{\circ} \mathrm{C}$. After incubation, the samples were placed on blood and MacConkey's agar kept in aerobic culture for 48 hours at $37^{\circ} \mathrm{C}$. For bacterial identification, Gram stain and oxidase test were performed, using absorbent paper impregnated with pphenylenediamine. Biochemical tests of the microbiological sample were performed using the Bactray I and II® kit (LaborClin-PR/Brazil).

The mare that aborted was 4 years old, primiparous and had natural coverage. The aborted fetus was found in the paddock by the owner in an adequate state of conservation, but the placenta was fragmented and dirty. There were no changes in physiological parameters in the mare immediately or after the abortion, but two months before showed lameness in the right pelvic limb. This lameness was related to a subsolar wound of approximately $1.5 \mathrm{~cm}$, characterized by an abscess with necrosis of the adjacent tissue, demonstrating sensitivity when clamping the hoof in the lateral region of the sole and lateral heel bulb, in addition to increased temperature in the region.

The abscess was treated with sulfamethoxazole + trimethoprim (Borgal ${ }^{\circledR}, 12 \mathrm{mg} / \mathrm{kg}+2.4 \mathrm{mg} / \mathrm{kg}$, IV, SID, for 7 days), Firocoxib (Previcox ${ }^{\circledR}, 0.1 \mathrm{mg} / \mathrm{kg}$, orally, SID, for 10 days) and Flunixin meglumine (Banamine $^{\circledR}, 1.1 \mathrm{mg} / \mathrm{kg}, \mathrm{IV}, \mathrm{SID}$, for 7 days) with clinical recovery after the end of treatment. In the same period, the mare showed a rectal temperature oscillating above $39.2^{\circ} \mathrm{C}$ for two days. At this time, Imidocarb dipropionate (Imizol ${ }^{\circledR}, 2,4 \mathrm{mg} / \mathrm{kg}$, IM in a single dose), Ringer Lactate $(20 \mathrm{~mL} / \mathrm{kg} / \mathrm{hr}$, IV, one hour per day, for three days) and L-ornithine aspartate $\left(\right.$ Ornitil $^{\circledR}$, $4 \mathrm{mg} / \mathrm{kg}$, IV, SID, for 3 days) were administered with clinical improvement after treatment.

On the property, all mares are vaccinated annually for rabies (Rabmune ${ }^{\circledR}$, Vallé), influenza, tetanus, 
rhinopneumonitis and encephalomyelitis (Lexington $8^{\circledR}$, Vencofarma), and for Herpesvirus (Pneumabort ${ }^{\circledR} \mathrm{k}+1 \mathrm{~b}$, Zoetis) in the 5th, 7th and 9th months of gestation. As for leptospirosis (Leptovacin ${ }^{\circledR}$, Biovet), the mare had been vaccinated only once 3 months before the abortion. The estate's herd consisted of 15 mares, five of which were pregnant, three with normal births, and two who had an abortion. The other mare on the property who had a reproductive disorder, also primiparous, aborted at seven months of gestation in September of the same year, without showing any clinical changes, but the fetus and placenta were not recovered for anatomopathological analysis, making the definitive etiological diagnosis impossible.

The fetus submitted to necropsy had a regular body condition. In the subcutaneous tissue of the ventral abdominal region, there was diffuse moderate edema. The liver was diffusely yellowish, moderately enlarged, and with rounded edges (Figure 1A). The myocardium had pale, multifocal and discrete areas, and the lungs were collapsed, heavy, and had a shiny appearance. The umbilical cord showed moderate thickening and was covered by discrete deposition of fibrin and purulent material (Figure 1B).

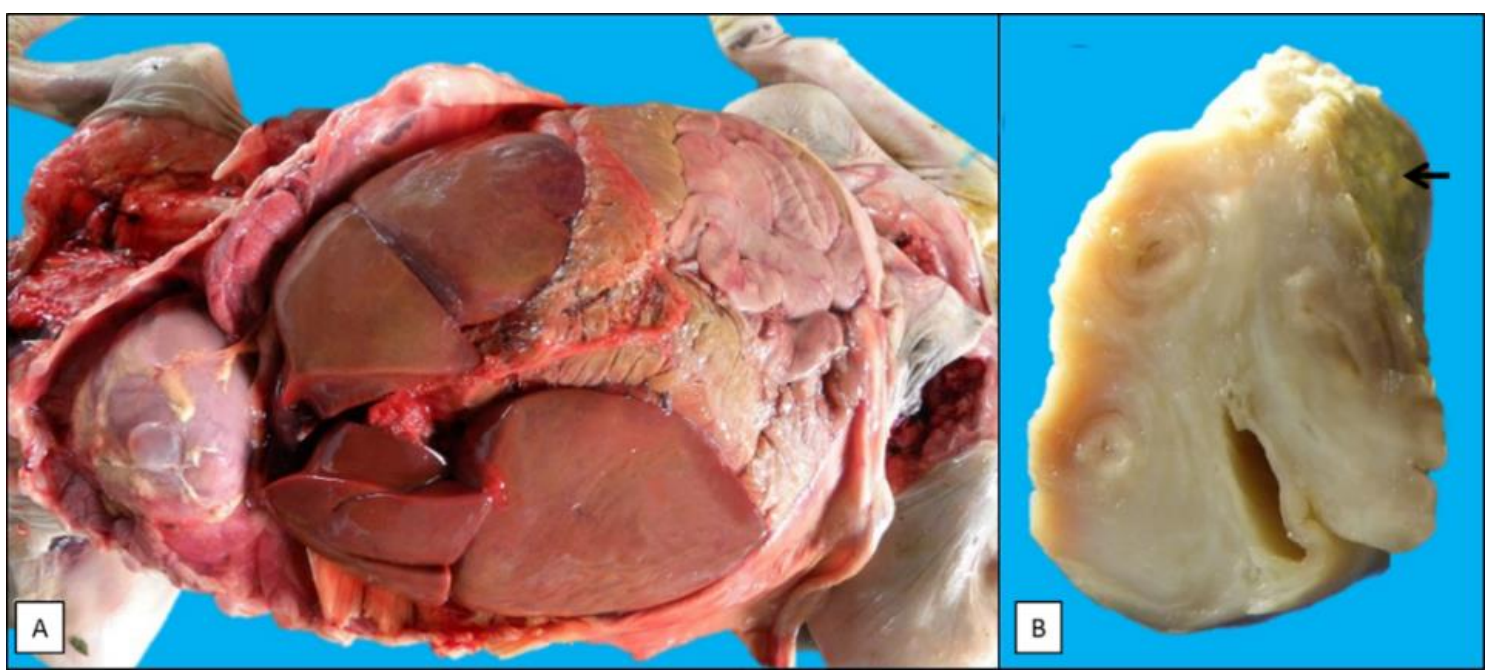

Figure 1. Sepsis by Yersinia enterocolitica in an aborted equine fetus. A) Liver: moderately increased in size and diffuse yellow. B) Umbilical cord: moderately thickened with discrete deposition of fibrin and purulent material (arrow).

In the histopathological analysis, there was myocardial necrosis with moderate multifocal mineralization (Figure 2A) associated with neutrophil infiltration, macrophages, lymphocytes and plasma cells, and thrombosis. In the lungs, an infiltrate composed of neutrophils, macrophages, lymphocytes and plasma cells, moderate diffuse was noted in the lumen of alveoli and bronchioles. The liver showed discrete multifocal fibrinoid necrosis associated with moderate infiltration of neutrophils, macrophages, lymphocytes and plasma cells. In the umbilical cord, there was moderate diffuse necrosis associated with moderate infiltration of neutrophils, macrophages, lymphocytes and plasma cells accompanied by deposition of fibrin bundles, intralesional bacterial myriads (Figure 2B) and thrombosis. In the kidneys, skeletal muscle, bladder, eyelid, and placenta there was discrete multifocal infiltration of neutrophils, macrophages, lymphocytes and plasma cells. In the lymph nodes was observed discrete diffuse lymphoid rarefaction.

In the microbiological evaluation on MacConkey agar countless colony-forming units, small, light pink or translucent and negative for lactose were observed. In the Blood agar, they were circular, small and grayish. The bacteria were Gramnegative coccobacilli and oxidase negative. In the biochemical identification of the pure culture growth, Y. enterocolitica was observed in the liver, lungs and stomach fluid. 

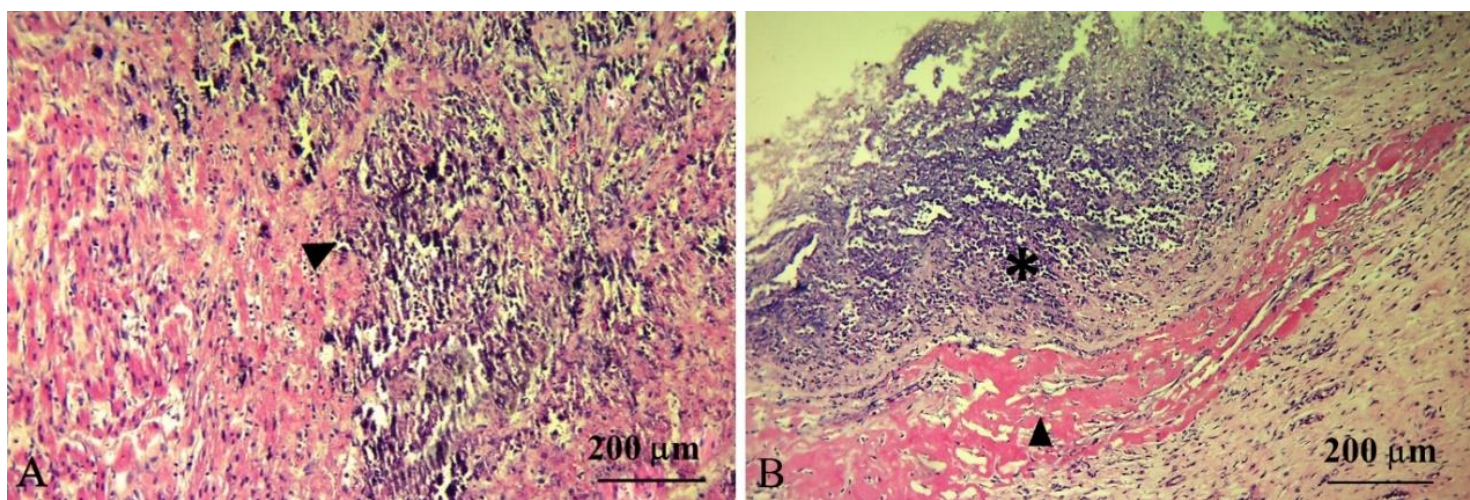

Figure 2. Sepsis by Yersinia enterocolitica in an aborted equine fetus. A) Moderate necrosuppurative myocarditis with mineralization (arrow). B) Moderate necrosuppurative omphalitis (asterisk), with deposition of fibrin plaques (arrow). H\&E.

\section{DISCUSSION}

The diagnosis of yersiniosis as the cause of abortion was defined considering the anatomopathological changes associated with bacterial isolation. The diagnostic approach used in the present case was similar to performed by other reports of infections caused by the same agent in abortions in sheep and sows (Corbel et al., 1992; Platt-Samoraj et al., 2009).

The main macroscopic changes in the fetus were observed in the liver, heart, and umbilical cord, and in reports of abortion in other species promoted by the same cause, the changes described in the liver were hyperemia and congestion (Corbel et al., 1992; Platt-Samoraj et al., 2009). In the heart, the changes differed from those found in a fetus of sheep, in which myocardial hemorrhage was observed (Corbel et al., 1992). In the present report, there were no macroscopic changes in lymph nodes, however, in previous reports, there was an increase in size and hyperemia (Corbel et al., 1992; Platt-Samoraj et al., 2009, 2010).

In histopathology, the lesions also differed from those previously described. In the abortion of the sheep, it was observed only vacuolization in cardiomyocytes (Corbel et al., 1992), and in the sows, no changes were described (Platt- Samoraj et al., 2010). The hepatic necrosis described in this report is compatible with those described in other species (Corbel et al., 1992; Platt- Samoraj et al., 2010). Pneumonia and nephritis have also been described in other reports, however, associated with congestion and hemorrhage
(Corbel et al., 1992; Platt-Samoraj et al., 2009, 2010). Rarefaction of the lymphoid population has been described in some lymphoid tissue in cases of abortions in sheep, in agreement with the changes found in the present report (Corbel et al., 1992). Additionally, in the present case, there was a necrosuppurative lesion without abscess formation, mainly in the liver and heart, which is a common lesion of $Y$. enterocolitica (Oellerich $e t$ al., 2007).

Experimentally $Y$. enterocolitica caused placentitis in sheep, resulting in predominant neutrophil infiltration, accompanied by necrosis and thrombosis (Corbel et al., 1992), whereas in the sows, necrosis and edema of the mucosa and placental vessels were observed (Platt-Samoraj et $a l ., 2010)$. The changes found in the placenta were results obtained only experimentally, with no spontaneous reports. The pathogenesis of placentitis is not completely elucidated, it is suggested that the infection occurs orally, having tropism through the intestinal epithelium, which can infect adjacent lymphoid tissues, and subsequently affect the blood circulation, leading to infection in other organs (Corbel et al., 1992; Platt-Samoraj et al., 2010). Fetal death can occur by placental failure or direct injury to the fetus (Corbel et al., 1992; Oellerich et al., 2007; PlattSamoraj et al., 2010). In this report, placentitis was mild, but histopathological and microbiological evaluations were compromised by tissue autolysis.

The equine fetus was aborted at seven months of gestation, however, there are no data on the interference of $Y$. enterocolitica infection during 
pregnancy of this species. The miscarriage may be related to the subsolar abscess that the mare had two months before the event. The experimental infection by $Y$. enterocolitica in pregnant sows demonstrated that the anatomopathological changes in the fetuses were more intense in the final stages of pregnancy, however, sows infected in the early stages showed chronic granulomatous inflammation in the lymphoid tissues (PlattSamoraj et al., 2010). In sheep, abortion occurred mainly in the final stage of pregnancy (Corbel et al., 1992; Giannitti et al., 2014).

Other species of Yersinia have already been reported as a cause of abortion in different species of animals. In sheep, $Y$. pseudotuberculosis is an important cause of abortion and stillbirth. The main anatomopathological lesions described in fetuses in these cases are necrosuppurative placentitis and pneumonia and, less frequently, necrosuppurative hepatitis, splenitis and nephritis (Giannitti et al., 2014). As differentials in this case, leptospirosis and infection with Equine Herpesvirus Type 1 are considered mainly, the latter being the most common viral cause of abortion in mares (Laugier et al., 2011; Marenzoni et al., 2012), but all mares of the property had a well-established vaccination protocol for both agents. To date, no specific tests have been performed to detect these agents.

In humans, the systemic infection caused by these bacteria is reported in both immunocompetent and immunocompromised people (Seto and Lau, 1984; Longenberger et al., 2013; Sauter et al., 2017). Yersiniosis is a food-borne disease of great importance for public health. Its zoonotic potential is mainly related to the consumption of contaminated products of animal origin (The European..., 2012). In a study with humans, $72.7 \%$ of patients diagnosed with $Y$. enterocolitica infection was contaminated by the consumption of products of animal origin, mainly dairy products (Longenberger et al., 2013).

Lameness injury is not believed to be associated with abortion since its complete resolution occurred 20 days earlier. Changes in body score, insufficient or poor quality food, interspecies confrontations, ascending co-infections by Streptococcus spp., E. coli, Klebsiella spp. and Pseudomonas spp. and changes in the reproductive tract would also be important differentials in cases of abortion in horses
(Laugier et al., 2011; Marenzoni et al., 2012), but all were excluded in the present report after accurate clinical and epidemiological investigations.

As for the source of the infection, it is noteworthy that although pigs are the main reservoirs of this agent (Platt-Samoraj et al., 2010; The European..., 2012), on this farm, the breeding is exclusive of horses, excluding them as the source of the infection. However, $Y$. enterocolitica has already been identified in the feces of some species of birds and in possums, animals that usually have access to the same environment as the horses on the farm. These animals are typically seed dispersers from the gastrointestinal tract, and can easily spread the pathogen, contaminating pastures and facilitating the infection of other animals (Silveira et al., 2018), being the most likely form of contamination of the mare in the present report.

\section{CONCLUSION}

This is the first report to completely describe sepsis in an equine fetus associated with $Y$. enterocolitica, based on the consulted literature. Yersinia enterocolitica should be investigated in cases of abortion in mares, serving as a differential diagnosis for other bacterial diseases in such reproductive disorder in the equine species.

\section{REFERENCES}

CORBEL, M.J.; ELLIS, B.; RICHARDSON, C.; BRADLEY, R. Experimental Yersinia enterocolitica placentitis in sheep. Br. Vet. J., v.148, p.339-349, 1992.

DAS, A.M.; PARANJAPE, V.L.; WINBLAD, S. Yersinia enterocolitica associated with third trimester abortion in buffaloes. Trop. Anim. Health Prod., v.18, p.109-112, 1986.

GIANNITTI, F.; BARR, B.C.; BRITO B.P. et al. Yersinia pseudotuberculosis infections in goats and other animals diagnosed at the California Animal Health and Food Safety Laboratory System: 1990-2012. J. Vet. Diag. Inv., v.26, p.8895, 2014. 
LAUGIER, C.; FOUCHER, N.; SEVIN, C. et al. A 24-year retrospective study of equine abortion in Normandy (France). J. Equine Vet. Sci., v.31, p-116-123, 2011.

LONGENBERGER, A.H.; GRONOSTAJ, M.P.; YEE, G.Y. et al. Yersinia enterocolitica infections associated with improperly pasteurized milk products: southwest Pennsylvania, MarchAugust 2011. Epidemiol. Infect., v.142, p.16401650,2013

MARENZONI, M.L.; LEPRI, E.; PROIETTI, P.C. et al. Causes of equine abortion, stillbirth and neonatal death in central Italy. Vet. Rec., v.170, p.261-262, 2012.

OELLERICH, M.F.; JACOBI, C.A.; FREUND, S. et al. Yersinia enterocolitica infection of mice reveals clonal invasion and abscess formation. Infect. Immun., v.75, p.3802-3811, 2007.

PLATT-SAMORAJ, A.; SZWEDA, W.; PROCAJLO, Z. et al. The influence of experimental Yersinia enterocolitica infection on the pregnancy course in sows-preliminary studies. 3. Histopathological lesions. Pol. J. Vet. Sci., v.13, p.129-135, 2010.
PLATT-SAMORAJ, A.; SZWEDA, W.; UGORSKI, M. Isolation of Yersinia enterocolitica from aborted fetuses and sows in pig farms with reproductive disturbances. Pol. J. Vet. Sci., v.12, p.189-193, 2009.

SAUTER, M.; VAVRICKA, S.R.; LOCHER, P. et al. Multilocular hepatic abscess formation and sepsis due to Yersinia enterocolitica in a patient with hereditary hemochromatosis and type 2 diabetes Mellitus. Case Rep. Gast., v.11, p.724728. 2017.

SETO, W.H.; LAU, J.T.K. Septiceaemia due to Yersinia enterocolitica biotype 1 in Hong Kong. J. Inf., v.8, p.28-33, 1984.

SILVEIRA, D.R.; MILAN, C.; FERRASSO, M.M. et al. Campylobacter jejuni, Campylobacter coli, Salmonella spp. E Yersinia enterocolitica isoladas de animais silvestres em um centro de reabilitação. Pesqui. Vet. Bras., v.38, p.18381843, 2018.

THE EUROPEAN Union summary report on trends and sources of zoonoses, zoonotic agents and foodborne outbreaks in 2010. EFSA J., v.10, 2597, 2012. 